\title{
INFLUENCE OF TRAUMA ON THE DEVELOPMENT OF CHRONIC INFLAMMATORY POLYARTHRITIS
}

\author{
BY
}

\author{
K. A. WILLIAMS AND J. T. SCOTT
}

Clinical Research Division, Kennedy Institute of Rheumatology, West London Hospital

This paper describes three patients in whom the onset of inflammatory polyarthritis was closely related to traumatic episodes involving the fingers.

Case 1, a male civil servant, was well until 1961 when, at the age of 31 years, he was doing some carpentry at home, planing a piece of wood in a vice. He is lefthanded and was therefore holding the handle of the plane in his left hand. During a forward stroke he hit the left middle finger against the vice at the level of the proximal interphalangeal joint. This was immediately followed by pain and swelling of the joint, which did not subside.

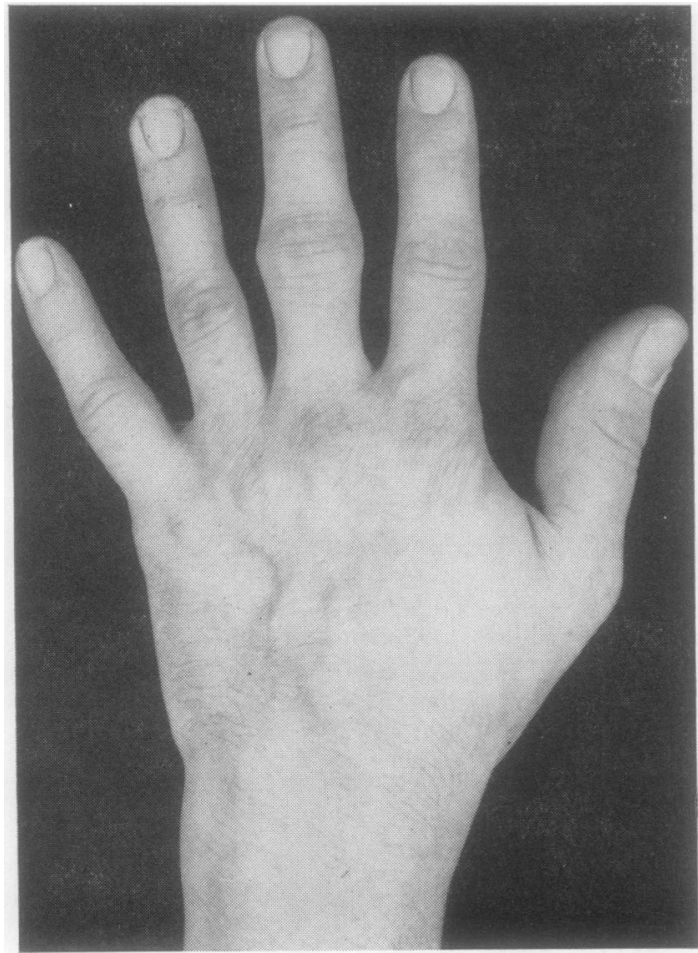

Fig. 1.-Case 1, left hand, showing soft tissue swelling of third proximal interphalangeal joint and wrist.
In 1962 there was the onset of persistent pain and swelling in both wrists. In 1966 he was first seen at the West London Hospital. There was now lack of full

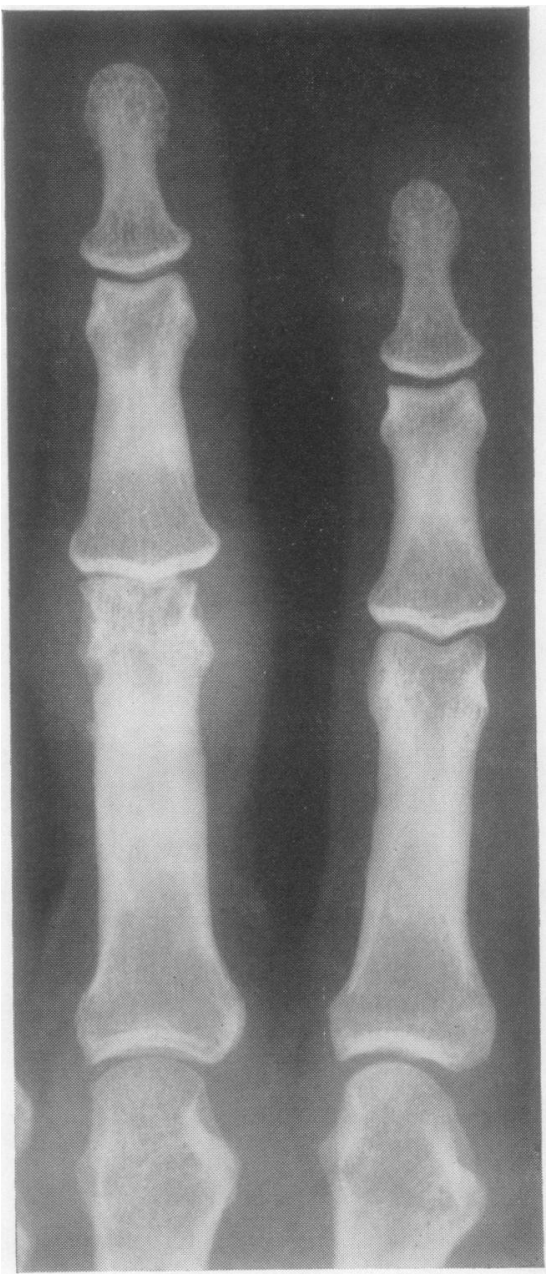

Fig. 2. Case 1, radiograph of second and third left fingers, showing Fig. 2. Case 1 , radiograph of second and third left fing therd proxim interphalangeal joint. 
extension of the elbows, soft tissue swelling of the wrists, and thickening of several metatarsophalangeal joints, swelling of the third left proximal interphalangeal joint being especially prominent (Fig. 1).

There was a small nodule on the left elbow which on biopsy showed central necrosis with surrounding pallisading of histocytes characteristic of rheumatoid disease. The erythrocyte sedimentation rate was $22 \mathrm{~mm}$./hr (Westergren), and the Waaler-Rose test was positive $1: 2048$.

Radiographs showed soft-tissue swelling and loss of cartilage in the third left proximal interphalangeal joint (Fig. 2). There was no radiological involvement in any of the other finger joints, but erosions were present in the wrists (Fig. 3) and in both first metatarsophalangeal joints (Fig. 4).

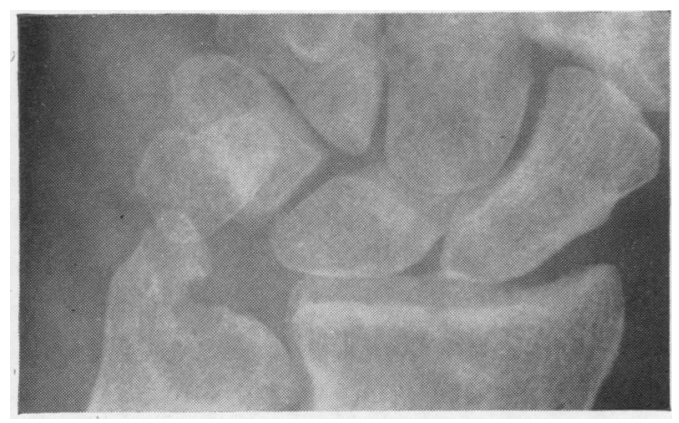

Fig. 3.-Case 1, radiograph of left wrist, showing erosive changes.
Comment.-Trauma appeared to determine the site of onset of nodular sero-positive rheumatoid arthritis at an interphalangeal joint.

Case 2, a male aeronautical engineer, was well until 1965 when, at the age of 51, he was sawing a piece of wood in a vice, against which he struck the third finger of the right hand at the level of the proximal interphalangeal joint. The joint was swollen and bruised for a few days but this subsided completely. Several weeks afterwards, however, there was the onset of persistent swelling of the same joint. About 3 months later he developed pain in the right elbow, right thumb, right knee, and both feet.

When first seen in 1966, he was found to have soft tissue swelling of the third right proximal interphalangeal joint which lacked $30^{\circ}$ of full extension; there was also some soft tissue swelling of the fourth right proximal interphalangeal joint (Fig. $5 a, b$, overleaf).

The only other clinical abnormality was some pain on movement of the left shoulder. The erythrocyte sedimentation rate was $16 \mathrm{~mm} . / \mathrm{hr}$, and the Waaler-Rose test positive $1: 512$.

Radiographs showed erosion at the third right proximal interphalangeal joint (Fig. 6, overleaf) but the other joints of the hands showed no bony changes. There were, however, erosions in several of the metatarsophalangeal joints (Fig. 7, overleaf).

Comment.-Trauma again appeared to influence the site of onset of sero-positive rheumatoid disease.
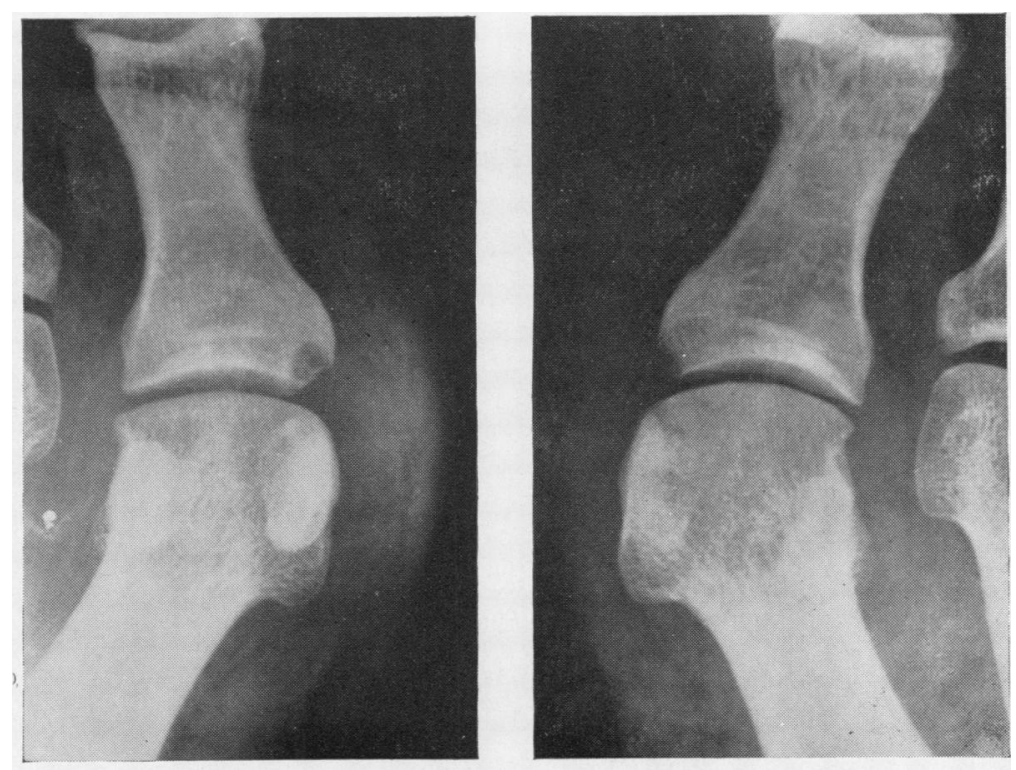

Fig. 4.-Case 1, radiographs showing erosions in both first metatarsophalangeal joints. 

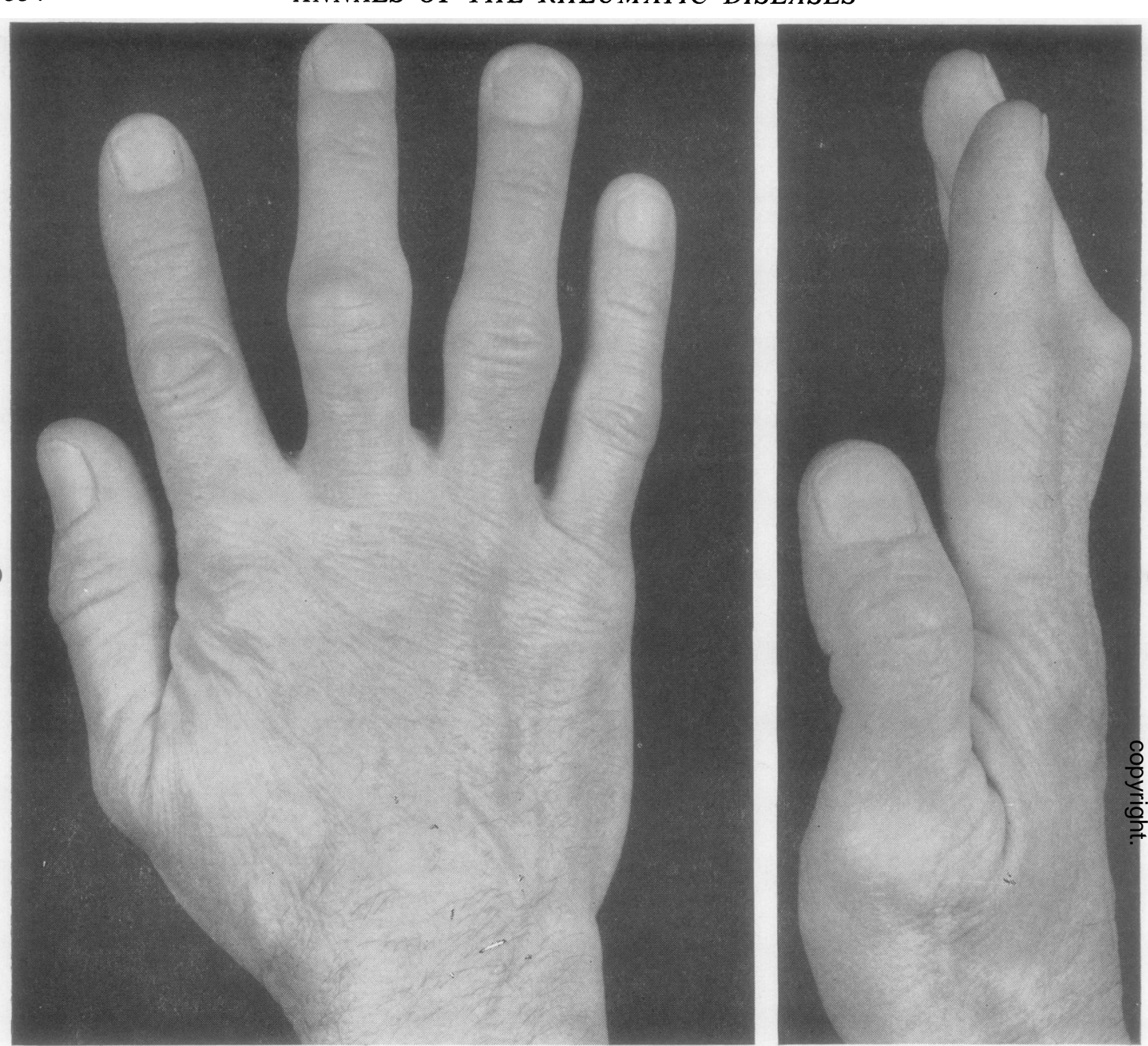

Fig. 5.-Case 2, dorsal (a) and lateral $(b)$ views of right hand, showing soft tissue swelling of third and fourth proximal interphalangeal joints and flexion contracture of middle finger.

(a)
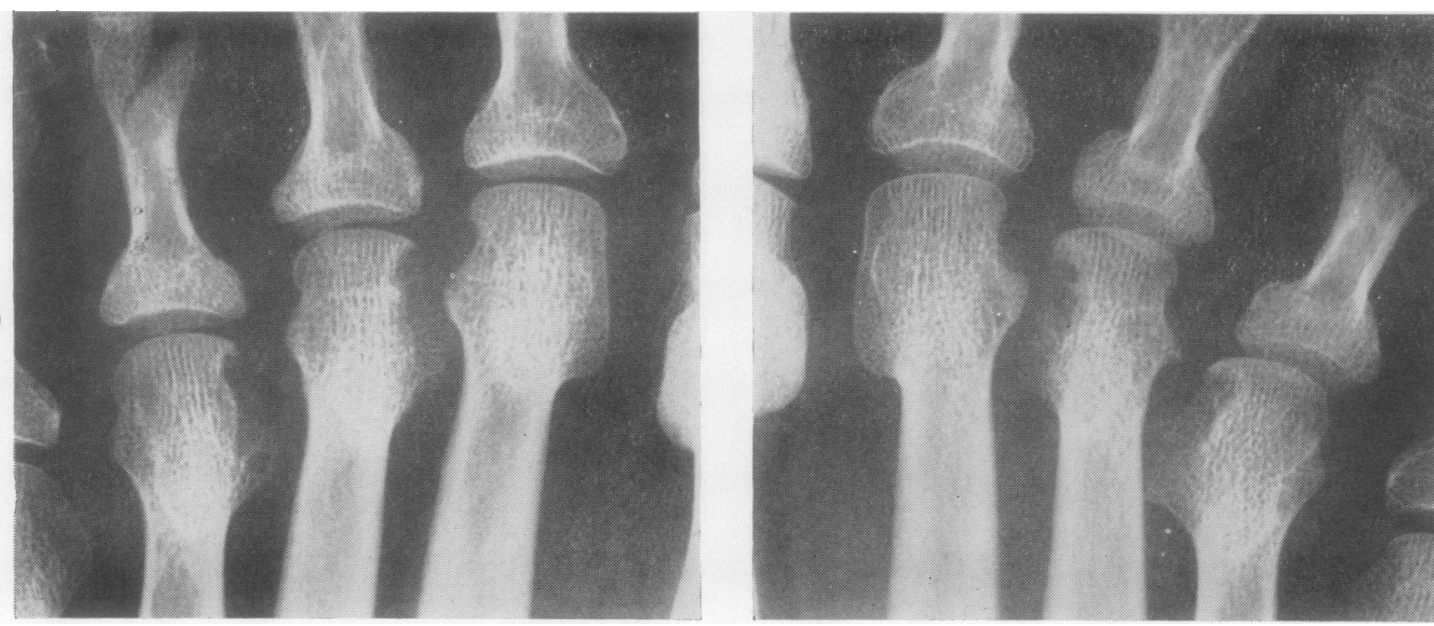

Fig. 7.-Case 2, radiographs of left ( $a$ ) and right $(b)$ metatarsal heads, showing erosive changes.

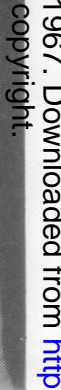

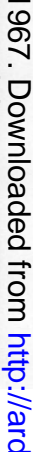




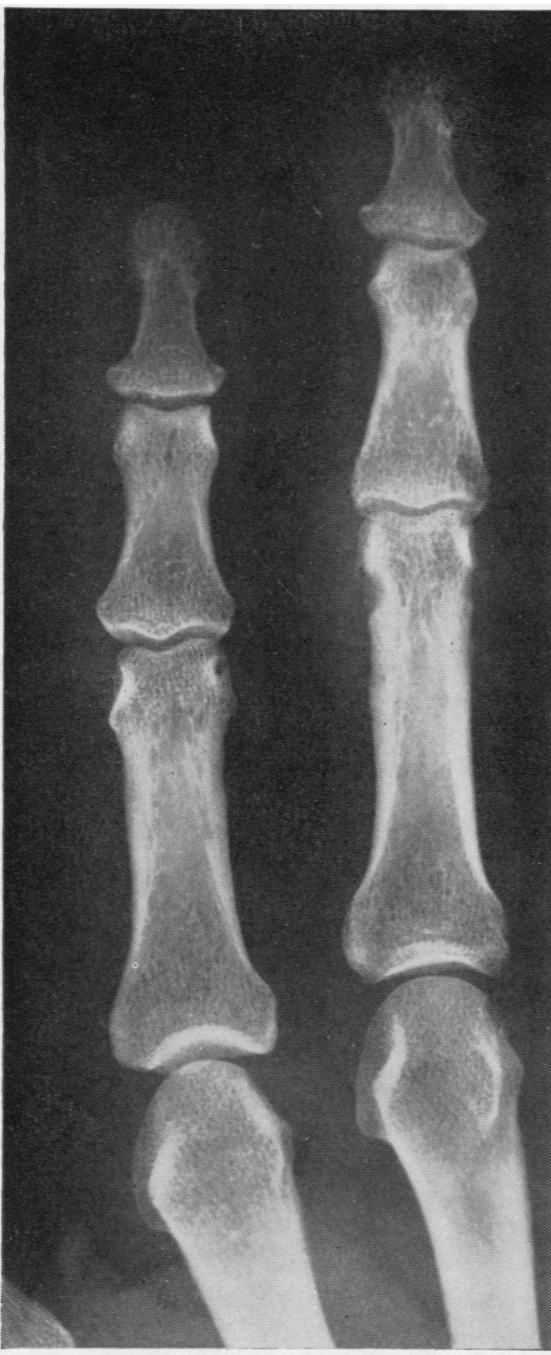

Fig. 6.-Case 2, radiograph of second and third right fingers, showing erosions of the third proximal interphalangeal joint.
Case 3, a female factory assembly worker, was well until March, 1965, when at the age of 54 she was using a pair of pliers which slipped so that she knocked the second and third right proximal interphalangeal joints against a bench. The second right proximal interphalangeal joint became rapidly swollen and slightly reddened.

When she was seen a few weeks later, the joint was found to be tender, swollen, and lacking $40^{\circ}$ of full extension. After 8 weeks, however, the inflammation in this joint subsided and full extension became possible. The third right proximal interphalangeal now became red and swollen, also lacking about $40^{\circ}$ extension (Fig. $8 a, b)$. There was some fluid in the flexor tendon sheath of the middle finger. The swelling and flexion deformity in this joint remained thereafter though all other joints were normal on clinical examination.

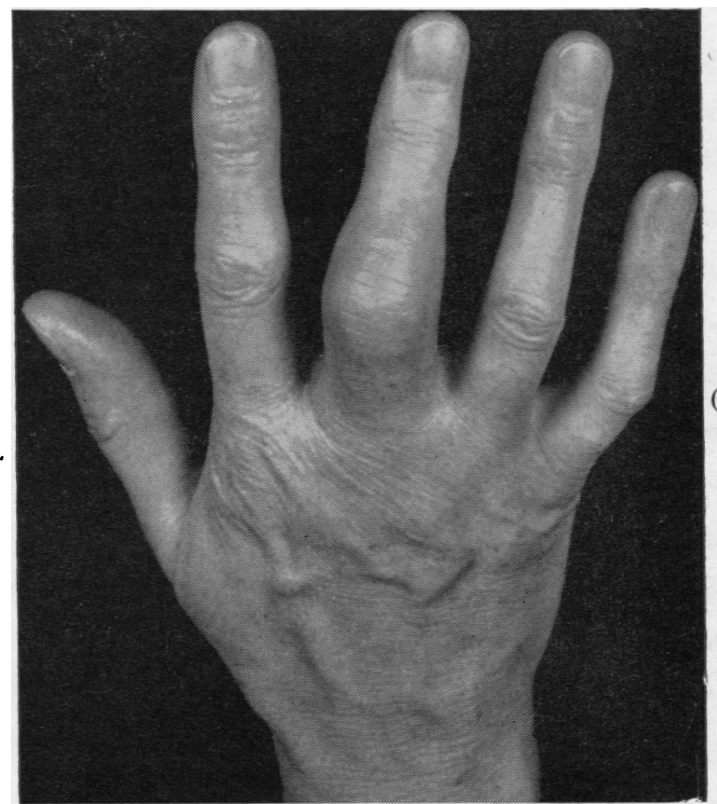

Fig. 8.-Case 3 dorsal (a) and lateral (b) views of right hand, showing swelling and flexion contracture of middle finger.

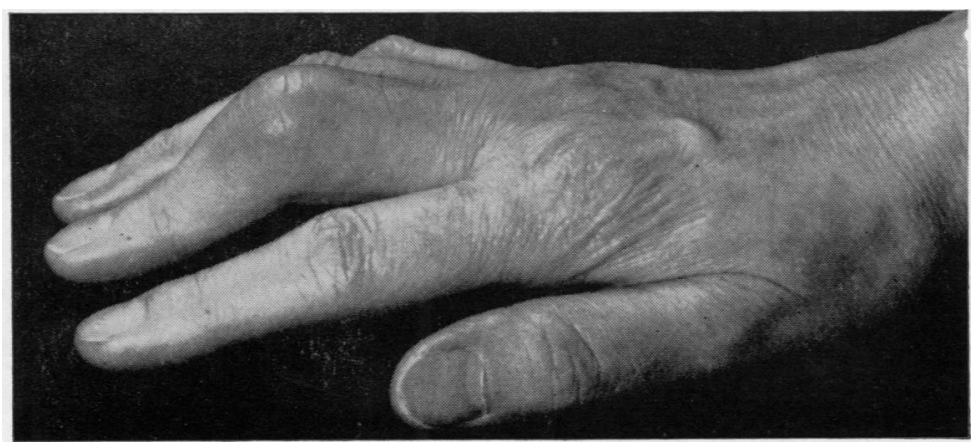

Fig. 8(b). 
The erythrocyte sedimentation rate was $30 \mathrm{~mm} . / \mathrm{hr}$, and the Waaler-Rose test negative 1:4. Radiographs showed erosive changes in the third right proximal interphalangeal and metacarpophalangeal joints with periosteal elevation (Fig. 9) but no erosions elsewhere in the hands and feet.

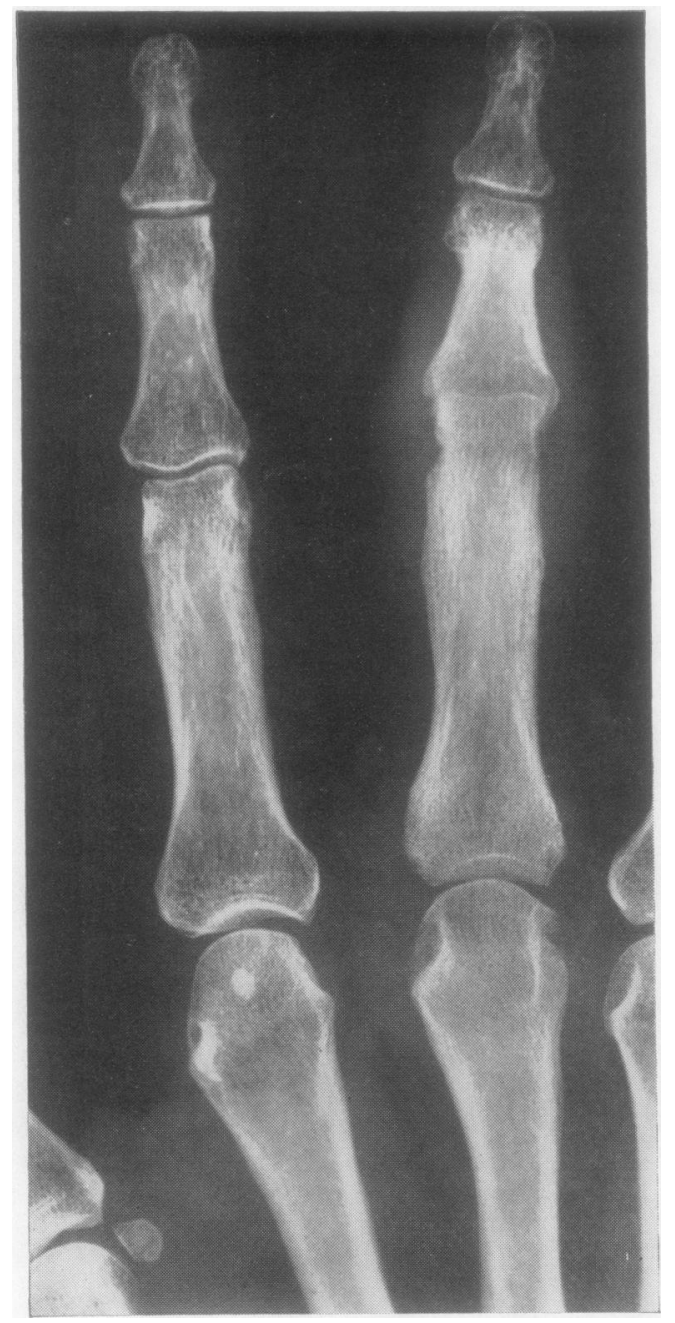

Fig. 9.-Case 3, radiograph of second and third right fingers, showing erosions in the third proximal interphalangeal and metacarpophalangea joints with periosteal elevation.

In May, 1966, she was noted to have a reddish scaling rash behind the ears and in the scalp. These lesions were thought to be psoriatic although there were no skin changes elsewhere. There was some doubt about their exact time of onset because the patient now stated that she had noticed the scalp lesions for about 3 years. No further joint changes have developed.

Comment.-Trauma appeared to influence the onset of arthritis and tenosynovitis in one finger. This may be psoriatic arthritis, although in this case there is as yet no evidence of arthritis elsewhere.

\section{Discussion}

The effect of trauma upon the development of rheumatoid arthritis has been the subject of several clinical studies. Rydén (1943) considered that trauma to a single large joint was a predisposing factor in nineteen out of 905 cases of chronic polyarthritis. Kelly $(1951 a, b ; 1957)$ gave brief case reports of 33 patients in whom trauma preceded the development of polyarthritis; in some of them there seemed to be a definite relation between specific damage to a single joint and its prominent involvement in subsequent generalized disease, but in others the situation was less clearly defined. Edström (1941) gave a detailed account of the inter-relationship between trauma and rheumatoid disease. Trauma was regarded as a precipitating factor in 72 out of his 2,034 patients. In all 72 the injured joint was the first to become affected by generalized disease, except that in four the process remained monarticular.

Apart from these descriptive accounts, several published series mention the incidence of trauma as a precipitating factor in the onset of rheumatois arthritis, though clinical details are not given: These reports are tabulated by Short, Bauer, an Reynolds (1957), who themselves found that fiftee of their 293 patients gave a history of trauma in association with the onset of arthritis. This frequency of $5 \cdot 1$ per cent. is fairly representative of the other series.

It is often difficult to assess the accuracy or $\overrightarrow{\vec{B}}$ significance of events which are stated to have 3 occurred before the onset of disease, but there seems little doubt that trauma played a part in determining the pattern of arthritis in our three patients. In Cases 1 and 2, with sero-positive rheumatoid arthritis, persistent involvement of a $\frac{5}{3}$ single injured joint was followed by generalized disease, although in Case 3, with probable psoriatic $\frac{O}{3}$ arthritis, the only joints so far involved have been those of the injured finger itself. In other reported $\frac{}{2}$ cases attention has been mainly directed to injuries $D$ to large joints, but in all three patients described here it has been the proximal interphalangeal joint of a $N$ middle finger which has been involved: this joint seems specially liable to minor injury. Two of the ${ }_{0}$ three patients were men and most of the case reports $\omega$ mentioned above also applied to men, in contrast to the female preponderance of rheumatoid disease in general. This must reflect the fact that men tend $\mathbb{\Phi}$ to engage in more strenuous physical activity than $\stackrel{?}{?}$ women and are therefore more exposed to the risk of $\frac{T}{0}$ 
trauma. In the same way large cystic erosions in established rheumatoid disease tend to occur in men engaged in active manual work (Castillo, El Sallab, and Scott, 1965),

Trauma has usually been described as a "precipitating" or "predisposing" factor in relation to the development of rheumatoid arthritis, implying perhaps that local damage in some way actually causes generalized arthritis. This is improbable; a more likely concept is that trauma to a joint occurring just before or about the time of onset of generalized disease renders that joint liable to especially severe involvement. There has been no opportunity to study the pathology of this situation and its mechanisms are as little understood as the rheumatoid process itself. There may be a connexion with the experimental studies of Dumonde and Glynn (1962) who produced an arthritis in rabbits indistinguishable from human rheumatoid disease by the intra-articular injection of human fibrin into previously sensitized animals; in some animals a similar arthritis was obtained when the rabbits' own fibrin was used for both initial immunization and subsequent intra-articular injection. As pointed out by Glynn and Holborow (1965), it is conceivable that a similar train of events could follow the deposition, by minor trauma, of a small quantity of homologous fibrin in a susceptible human joint.

\section{Summary}

Details are presented of three patients in whom trauma to the proximal interphalangeal joint of a middle finger was followed by chronic arthritis with prominent involvement of the injured joint. Two of the patients developed generalized sero-positive rheumatoid disease. In the third the arthropathy was probably psoriatic and has remained confined to the joints of the injured finger. Trauma therefore appeared to play a significant part in determining the pattern of arthritis.

\section{REFERENCES}

Castillo, B. A., El Sallab, R. A., and Scott, J. T. (1965). Ann. rheum. Dis., 24, 522 (Physical activity, cystic erosions, and osteoporosis in rheumatoid arthritis).

Dumonde, D. C., and Glynn, L. E. (1962). Brit.J. exp. Path., 43, 373 (The production of arthritis in rabbits by an immunological reaction to fibrin).

Edström, G. (1941). Acta med. scand., 108, 414 (Klinische Studien über den chronischen Gelenkrheumatismus).

Glynn, L. E., and Holborow, E. J. (1965). “Autoimmunity and Disease”, pp. 132-157. Blackwell, Oxford.

Kelly, M. (1951a). Med.J. Aust., 2, 197 (Chronic polyarthritis and monoarticular trauma).

- (1951b). Ann. rheum. Dis., 10, 307 (Monarticular trauma and rheumatoid arthritis).

- (1957). Acta rheum. scand., 3, 203 (Reversal of general rheumatic spread during active immobilization of wrists).

Rydén, E. (1943). Acta med. scand., 114, 442 (Chronic polyarthritis and trauma).

Short, C. L., Bauer, W., and Reynolds, W. E. (1957). "Rheumatoid Arthritis", p. 180. Harvard University Press, Cambridge, Mass.

L'influence du traumatisme sur le développement de la polyarthrite chronique inflammatoire

\section{RÉSUMÉ}

On présente trois cas de traumatisme de l'articulation interphalangienne proximale du medius ayant été suivi d'une arthrite chronique avec atteinte prédominante de l'articulation traumatisée. Deux de ces malades présentèrent une maladie rhumatoïde généralisée séropositive. Chez le troisième malade l'arthropathie fut probablement d'origine psoriasique et demeura limitée aux articulations du doigt traumatisé. Il semble donc que le traumatisme ait joué un rôle significatif sur la détermination du caractère de l'arthrite.
El efecto del traumatismo sobre el desarrollo de la poliartritis crónica inflamatoria

SUMARIO

Se presentan tres casos de traumatismo de la articulación interfalangiana proximal del dedo medio, seguida de artritis crónica afectando principalmente la articulación traumatizada. Dos enfermos presentaron una enfermedad reumatoide generalizada seropositiva. En el tercer enfermo la artropatía fué probablemente de origen psoriásico y quedó limitada a articulaciones del dedo traumatizado. Parece, pués, que el traumatismo había desempeñado un papel significativo en la determinación del caracter de la artritis. 